\title{
Rancang Bangun Permintaan Benang Dengan Implentasi Metode Model View Controller Pada PT Indo Taichen Textile Industry
}

\author{
Noer Azni Septiani ${ }^{1}$, Fahlepi Roma Doni ${ }^{2}$, Wahyudin ${ }^{3}$ \\ 1,2,3Universitas Bina Sarana Informatika \\ 1e-mail: noer.nas@bsi.ac.id \\ 2e-mail: fahlepi.fro@bsi.ac.id \\ 3e-mail: wahyudin.whd@bsi.ac.id
}

\begin{abstract}
Abstrak
Permintaan benang yang masih tidak teratur dan panjang karena jarak antara gudang benang dan pabrik kain rajut mengakibatkan penggunaan benang untuk produksi kain menjadi terhambat, tidak efisien dalam waktu pemrosesan sementara permintaan untuk pengadaan benang diperlukan dengan cepat. Tujuan dari penelitian ini adalah untuk membuat pengadaan benang di PT Indo Taichen Textile Industry menjadi lebih cepat dan lebih efisien dengan membuat benang berbasis web untuk memfasilitasi setiap departemen dalam proses Permintaan benang. Solusi untuk menyelesaikan masalah ini yang Dalam pembuatan situs web ini penulis juga menerapkan metode MVC sebagai opsi dalam pengembangan sistem. Model View Controller (MVC)dengan membuat aplikasi atau program berbasis web PT Indo Taichen Textile Industry, hasil dari aplikasi berbasis web ini dapat mengurangi kelemahan sistem, mempercepat proses pengadaan Dari utas, penyimpanan data bisa lebih mudah dan benar karena data tersebut disimpan dalam database sehingga akses data dan pembaruan data dapat dilakukan secara terkendali, mengatur pengadaan barang dan melihat perkembangan pengadaan barang di PT. Industri Tekstil Indo Taichen.
\end{abstract}

Kata kunci: Permintaan, Benang, PT Indo Taichen, Industri,Tekstil, MVC

\begin{abstract}
The demand for yarn is still irregular and long because the distance between the yarn warehouse and the knit fabric factory has resulted in the use of threads for fabric production being hampered, inefficient at processing time while the demand for yarn procurement is needed quickly. The purpose of this research is to make the procurement of yarn at PT Indo Taichen Textile Industry to be faster and more efficient by creating web-based threads to facilitate each department in the process of requesting threads. Solution to solve this problem In the making of this website the author also applies the MVC method as an option in system development. Model View Controller (MVC) by creating an application or web-based program PT Indo Taichen Textile Industry, the results of this web-based application can reduce system weaknesses, speed up the procurement process From threads, data storage can be easier and more correct because the data is stored in the database so Data access and data updates can be carried out in a controlled manner, regulating the procurement of goods and seeing the progress of the procurement of goods at PT. Taichen Indo Textile Industry.
\end{abstract}

Keywords: Demand, Yarns, PT Indo Taichen, Industry, Textiles, MVC

\section{Pendahuluan}

Permintaan barang berupa benang dari Gudang ke departemen Knitting memiliki kontribusi besar dalam produksi kain pada PT Indo Taichen Textile Industry. Akan tetapi jarak antara departemen Knitting dan departemen GDB yang jauh membutuhkan waktu yang lama sehingga menghambat produksi kain. Mengendalikan persediaan dengan tepat bukanlah hal yang mudah. Jumlah persediaan yang terlalu besar akan mengakibatkan timbulnya dana yang dikeluarkan menjadi terlalu besar, selain itu resiko kerusakan bahan baku juga menjadi lebih besar (Fauzi \& Hartono, 2019).

Banyaknya permintaan konsumen terhadap perusahaan, membuat produksi perusahaan 
mengalami keterlambatan untuk pengiriman (Pt, Kurnia, \& Sejati, 2018).

perubahan permintaan konsumen terhadap produk, sering terlambatnya material bahan baku, sub material dan absensi pegawai, dan mengenai penyediaan material bahan baku yang sering terlambat kedatangannya (Fauzi \& Hartono, 2019).

Hasil dari splikasi berbasis web ini dapat mengurangi kelemahan sistem, penyimpanan data bisa dilakukan dengan aman, mudah dan benar karena data disimpan dalam sebuah database sehingga pengaksesan data dan update data dapat dilakukan secara terkendali(Septiani, 2018) Beberapa penelitian memperlihatkan bahwa ada hubungan tidak langsung antara hasil pelaksanaan pengadaan dengan kualitas hasil pelaksanaan pekerjaan (Wiyana, 2012).

Permasalahan persediaan kerap kali dihadapi oleh para pengambil keputusan khususnya dalam hal manajemen persediaan (Simamora, Puspita, \& Herrhyanto, n.d.,2019)

Persediaan bahan baku dimaksudkan untuk memenuhi kebutuhan bahan baku untuk proses produksi pada waktu yang akan datang (Irawan, 2018).

Tujuan dari penelitian ini adalah untuk mengetahui permohonan benang yng efisien, dan mengetahui metode alternatif pengendalian persediaan bahan baku yang dapat digunakan oleh perusahaan.Kualitas merupakan syarat penting yang harus dipenuhi oleh perusahaan dalam rangka memproduksi barang dan jasa demi mencapai kepuasan pelanggan (Sihombing \& Sumartini, 2018).

pentingnya penggunaan Teknologi Informasi (TI) sebagai kesempatan untuk mengubah pola bisnis yang konvensional (masih menggunakan paper based) menjadi bisnis yang berbasis elektronik (e-business). Saat ini teknologi informasi sudah banyak dimanfaatkan oleh perusahaanperusahaan di berbagai bidang industri(Utama, 2019). Model View Controller (MVC) merupakan design pattern yang terdiri dari design pattern yang lain disebut sebagai compound pattern(Endra \& Aprilita, 2018).

Model View Controller (MVC) adalah sebuah sebuah metode untuk membuat sebuah aplikasi dengan memisahkan data dari tampilan dan cara memprosesnya. MVC diperkenalkan pertama sekali oleh para peneliti di XEROC PARAC yang bekerja untuk pembuatan bahasa pemrograman
Smalltalk pada tahun 1970-1980 (Rahmadiansyah \& Irwan, 2012).

Model View Controller (MVC) adalah sebuah konsep yang diperkenalkan oleh penemu Smalltalk (Trygve Reenskaug) untuk membuat satu jenis data jaringan menjadi jenis data lainnya bersama dengan pemrosesan (model), mengisolasi dari proses manipulasi (controller) dan tampilan (view) untuk direpresentasikan pada sebuah user interface (Wijaya \& Christian, 2019)

\section{Metode Penelitian}

Penelitian ini menggunakan metode kualitatif deskriptif, bertujuan untuk mendeskripsikan apa-apa yang saat ini berlaku. Di dalamnya terdapat upaya mendeskripsikan, mencatat, analisis dan menginterpretasikan kondisi yang sekarang ini terjadi atau ada. Dengan kata lain penelitian deskriptif kualitatif ini bertujuan untuk memperoleh informasi informasi mengenai keadaan yang ada (Sitokdana \& Tanaamah, 2018).

Adapun langkah-langkah dalam penelitian sebagai berikut:

\subsection{Teknik Pengumpulan Data}

Dalam penyusunan jurnal ini, penulis dalam proses penelitiannya menggunakan beberapa teknik pengumpulan data untuk memperoleh data dan informasi yang diperlukan. Berikut ini teknik pengumpulan data yang digunakan:

\section{a. Observasi (Observation)}

Dalam hal ini, penulis melakukan teknik pengumpulan data dengan melakukan proses pengamatan secara langsung pada PT Indo Taichen Textile Industry, untuk mengamati kegiatan yang sedang berlangsung dan mengumpulkan data yang berkaitan dengan informasi permohonan benang pada PT Indo Taichen Textile Industry.

b. Wawancara (Interview)

Dalam hal ini, penulis melakukan teknik pengumpulan data dengan melakukan proses wawancara secara langsung dengan pihak perusahaan yang terkait di dalamnya, seperti karyawan pada departemen Knitting, RMP dan GDB yang terlibat di dalam perusahaan tersebut, guna mendapatkan informasi yang ada pada pada PT Indo Taichen Textile Industry.

\section{c. Studi Pustaka (Literature)}


Penulis melakukan penelitian kepustakaan untuk memperoleh aspekaspek teoritis dalam pengumpulan data dan informasi melalui buku referensi, jurnal ilmiah dan materi lainnya yang berhubungan dengan masalah yang ditinjau dalam penyusunan jurnal ini.

\subsection{Model Pengembangan Sistem}

Model-View-Controller (MVC) adalah sebuah konsep yang diperkenalkan oleh penemu Smalltalk (Trygve Reenskaug) untuk membuat satu jenis paket data jaringan menjadi jenis data lainya bersama dengan pemrosesan (model), dari proses manipulasi (controller) dan tampilan (view) untuk dipresentasikan pada sebuah user interface (Wijaya \& Christian, 2019).

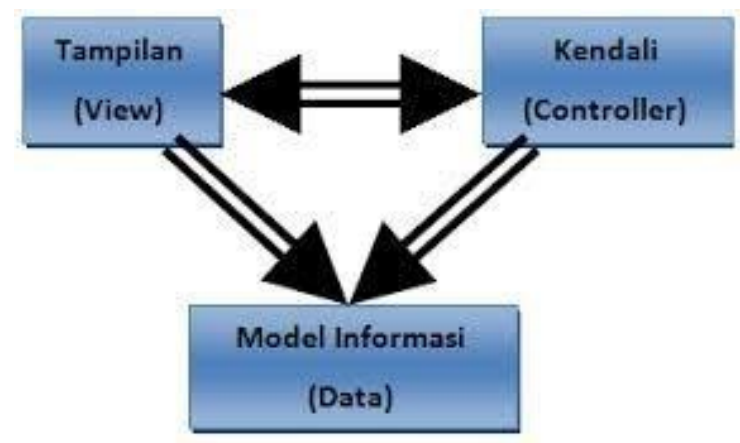

Sumber : (Wijaya \& Christian, 2019)

Gambar 1. Metode MVC

Keterangan menurut gambar diatas alur dari Model View Controller sebagai berikut:

a. Model

Model adalah bagian kode program yang menangani database, isi dari model merupakan bagian (fungsifungsi) yang berhubungan langsung dengan database untuk mengelola data seperti memasukkan data, pembaruan data, hapus data, dan lain-lain, namun tidak dapat berhubungan langsung dengan bagian view.

b. View

Tampilan (View). Bagian ini mengandung keseluruhan detail dari implementasi user interface. View adalah bagian kode program yang mengatur tampilan website. View biasanya berupa file skrip HTML. View juga berfungsi menampilkan data serta inputan user, jadi view merupakan halaman web.

\section{c. Controller}

Cara pemrosesan (Controller). Controller merupakan bagian yang menghubungkan model dan view. Controller berisi perintah-perintah yang bertanggung jawab untuk memproses suatu data dan mengirimkannya ke halaman web. Controller berfungsi untuk menerima request dan data dari user kemudian menentukan apa yang akan diproses oleh aplikasi.

\section{Hasil dan Pembahasan}

3.1. Proses Bisnis Sistem

Dalam hal ini, penulis akan membahas proses bisnis sistem yang menjelaskan tentang bagaimana pihak atau elemen yang terkait di departemen tersebut melakukan serangkaian aktivitas yang berhubungan dengan kegiatan permohonan benang pada PT Indo Taichen Textile Industry. Berikut ini penjelasannya:

Staff Pemohon membuat bon permohonan benang setelah itu bon diberikan ke Staff RMP untuk dicek apakah sesuai dengan kebutuhan order yang akan diproduksi. Bon dianalisa terlebih dahulu jika tidak sesuai bon akan dibuat lagi dan jika sesuai bon akan diberikan ke Staff GDB. Bon yang diterima akan dicek lagi. Apabila stok benang yang ada di bon tersedia maka akan direalisasi dan jika tidak bon akan dibatalkan atau dikembalikan ke Staff Pemohon untuk dibuatkan lagi.

Dan berikut ini activity diagram sistem berjalan yang berhubungan dengan kegiatan permohonan benang Departemen Knitting Pada PT Indo Taichen Textile Industy: 


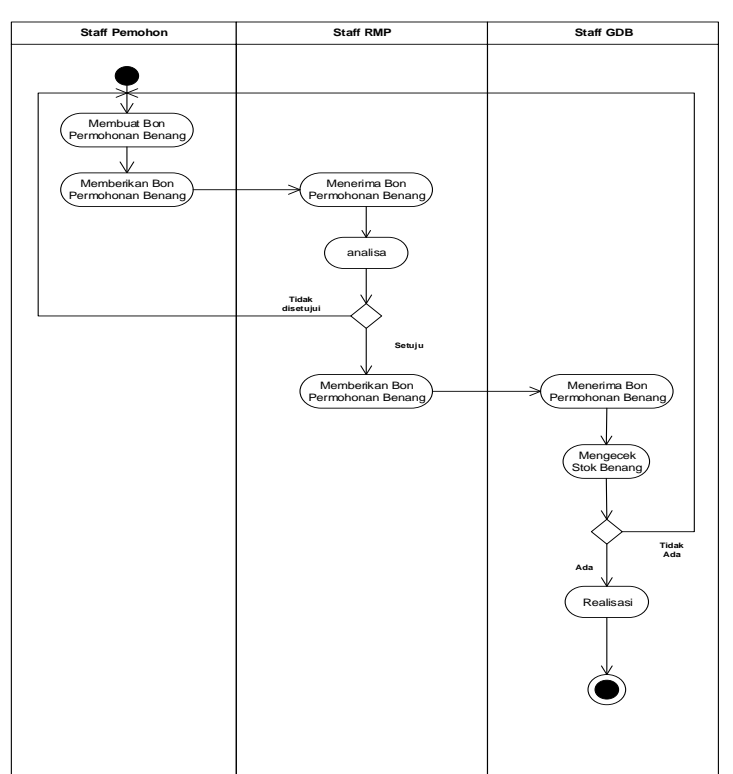

Gambar 1. Activity Diagram Sistem Berjalan Permohonan Benang

\subsection{Rancangan Sistem Dan Program Usulan}

a. Tahapan Analisis

Dalam tahapan analisis ini menjelaskan tentang analisa bagaimana pihak atau elemen yang terkait Pada PT Indo Taichen Textile Industry melakukan serangkaian aktivitas baik dengan pihak luar maupun internal yang berhubungan dengan pembuatan aplikasi dalam kaitannya terhadap analisa kebutuhan software.

1. Halaman Admin Staff Pemohon

A.1.Melakukan Login untuk masuk ke halaman utama

A.2.Membuat bon permohonan benang

A.3.Mengubah bon permohonan benang

A.4.Menghapus bon permohonan benang

A.5.Melihat Data Terima RMP

A.6.Melihat Data Terima GDB

A.7.Melihat Data Realisasi GDB

2. Halaman Admin Staff RMP

B.1. Melakukan Login untuk masuk ke halaman utama

B.2. Melihat Data Permohonan benang

B.3. Mengubah Data Terima RMP

3. Halaman Admin Staff GDB

C.1.Melakukan Login untuk masuk ke halaman utama

C.2.Melihat Data Permohonan Benang

C.3.Mengubah Data Terima GDB

C.4.Mengubah Data Realisasi GDB

\section{b. Use Case Diagram}

Sebuah Use Case Diagram pada dasarnya menggambarkan atau mendeskripsikan fungsi dari sebuah sistem. Dengan adanya Use Case Diagram tersebut pengguna dapat mengerti dan memperspektifkan sistem yang ada.

Adapun gambaran mengenai Use Case Diagram sistem informasi manajemen proyek berbasis web ini, adalah sebagai berikut:

1. Use Case Diagram Halaman Admin Staff Pemohon

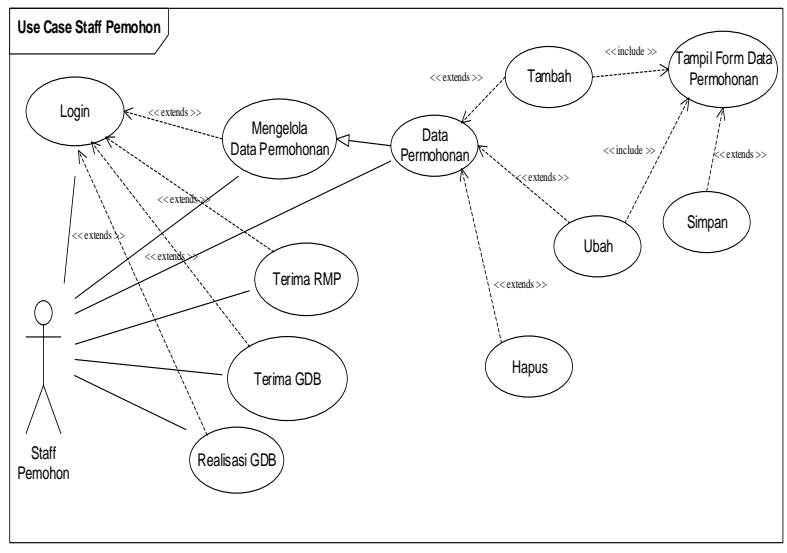

Gambar 2. Use Case Diagram Halaman Admin Staff Pemohon

\section{Use Case Diagram Halaman Admin Staff RMP}

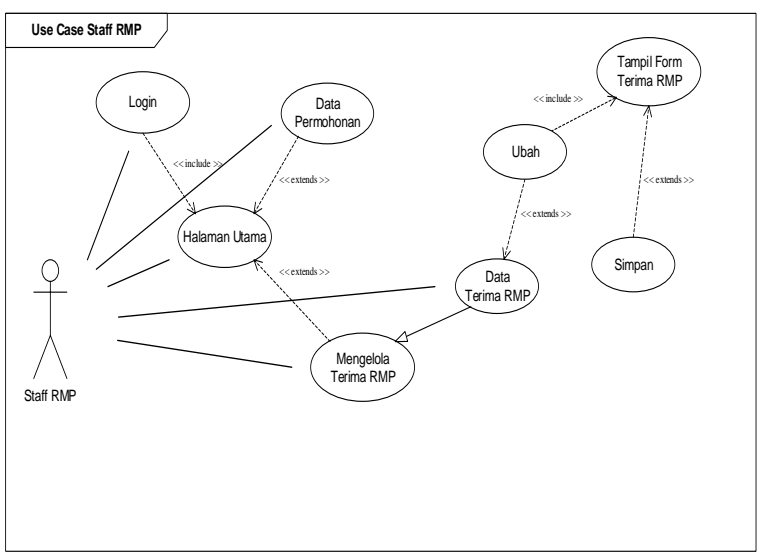

Gambar 3. Use Case Diagram Halaman Admin Staff RMP

3. Use Case Diagram Halaman Admin Staff GDB 


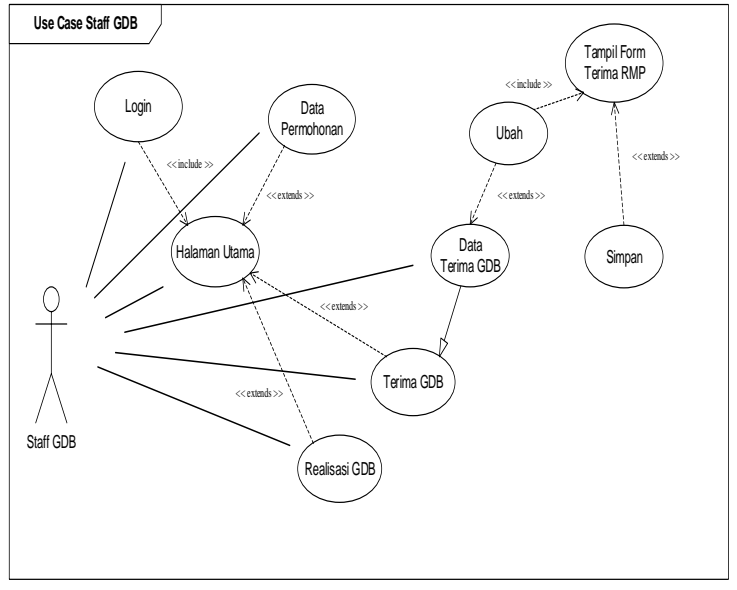

Gambar 4. Use Case Diagram Halaman Admin Staff GDB

\section{c. Activity Diagram}

Dalam sistem informasi manajemen proyek berbasis web ini, Activity Diagram yang ada adalah sebagai berikut:

\section{Activity Diagram Halaman Admin Staff}

\section{Pemohon}

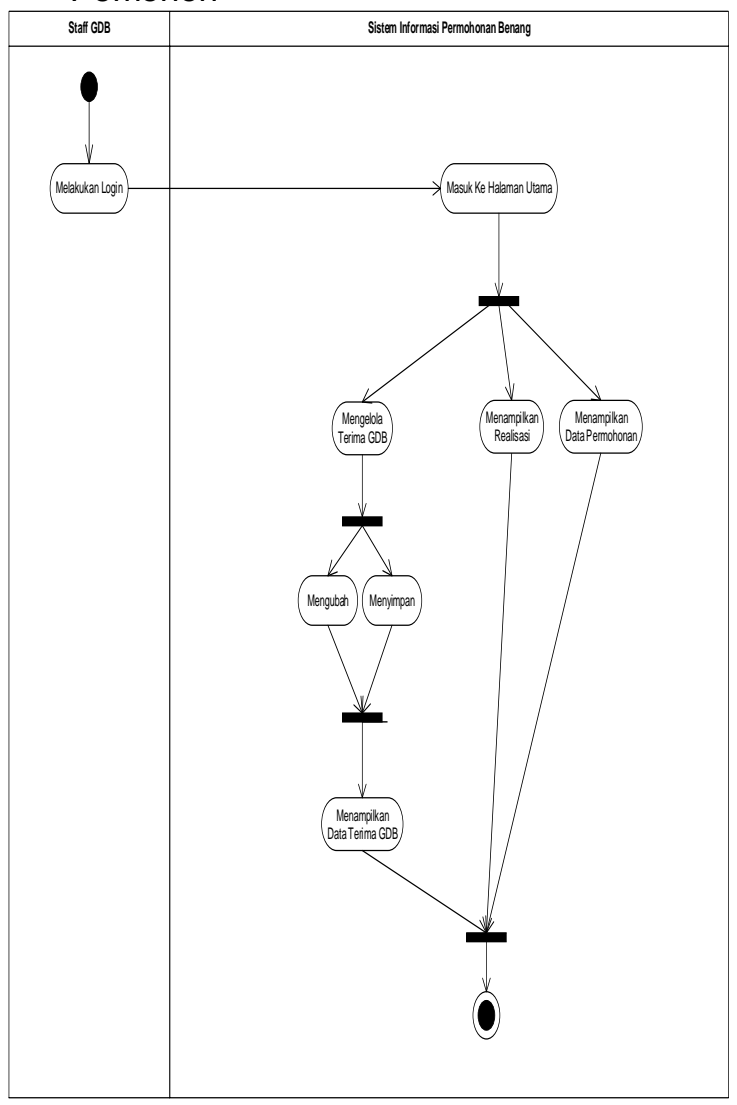

Gambar 5. Activity Diagram Halaman Admin Staff Pemohon

2. Activity Diagram Halaman Admin Staff RMP

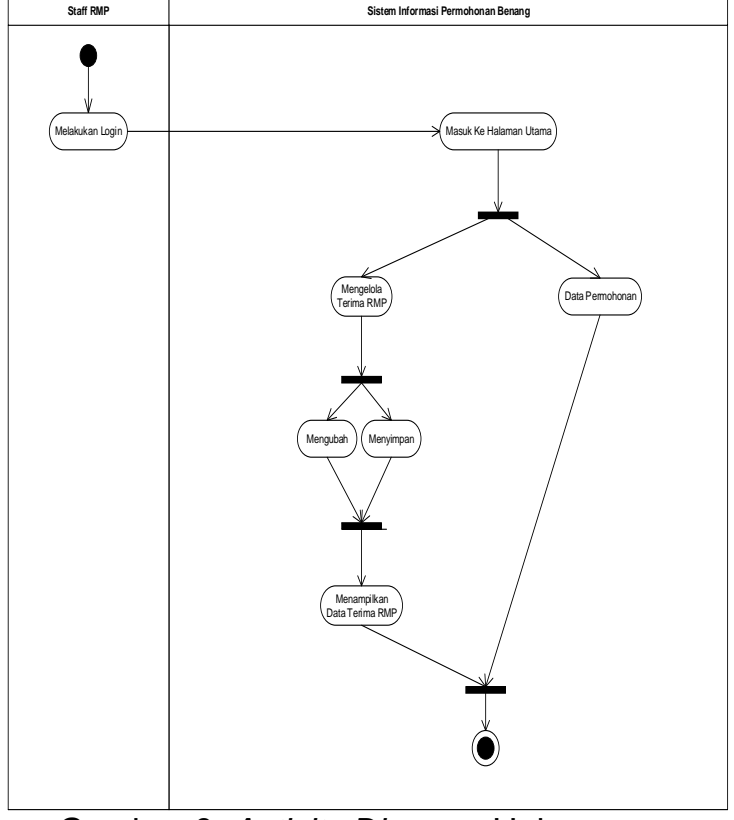

Gambar 6. Activity Diagram Halaman Admin Staff RMP

3. Activity Diagram Halaman Admin Staff RMP

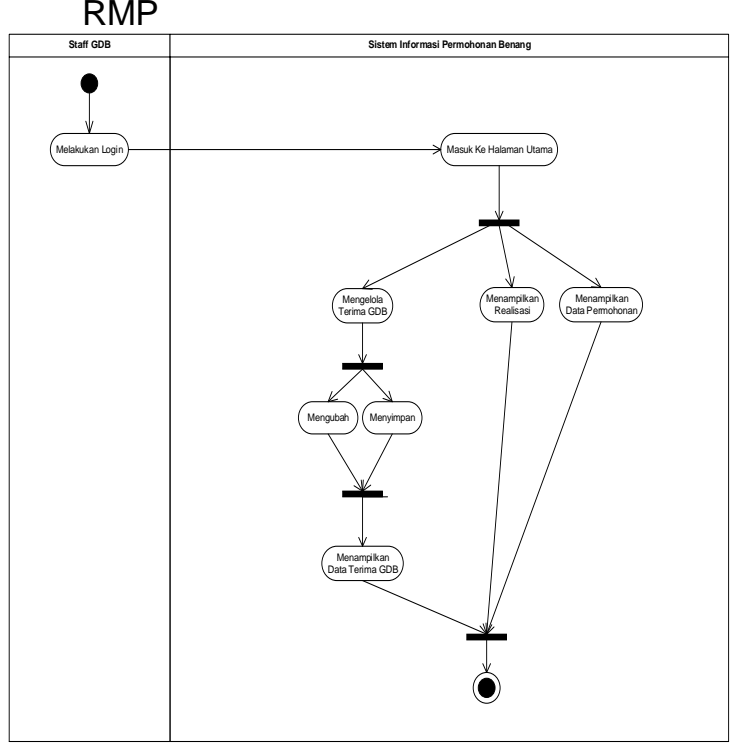

Gambar 7. Activity Diagram Halaman Admin Staff GDB

d. Entity Relationship Diagram (ERD)

Entity Relationship Diagram (ERD) menjelaskan hubungan antar data dalam basis data yang terdiri dari objek-objek dasar yang mempunyai hubungan atau nilai antar objek-objek tersebut. Adapun bentuk Entity Relationship Diagram (ERD) yang terdapat pada sistem ini sebagai berikut: 


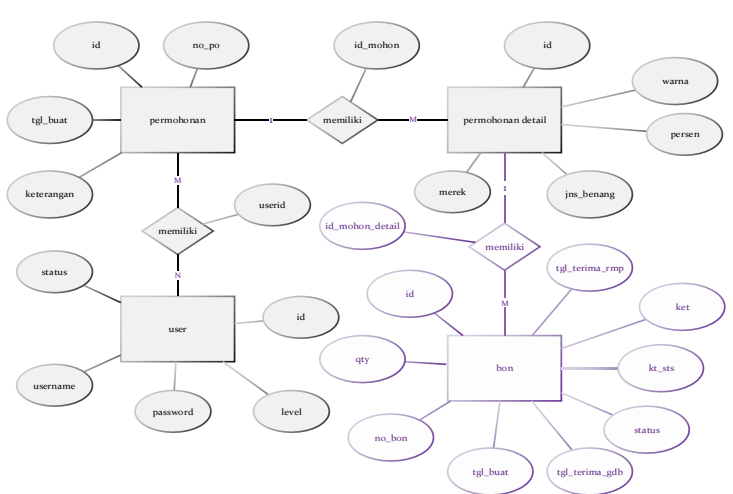

Gambar 8. Entity Relationship Diagram (ERD)

e. Logical Record Structure (LRS)

Logical Record Structure (LRS) dapat dikatakan sebagai bentuk representasi dari struktur record-record pada tabel-tabel yang terbentuk dari hasil antar himpunan entitas. Adapun bentuk Logical Record Structure (LRS) yang terdapat pada sistem ini ialah sebagai berikut:

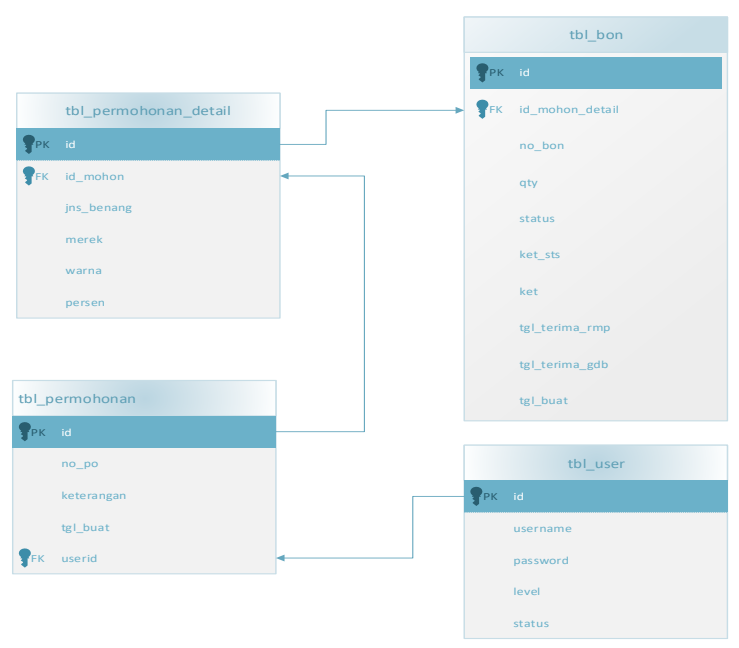

Gambar 9. Logical Record Structure (LRS)

f. Component Diagram

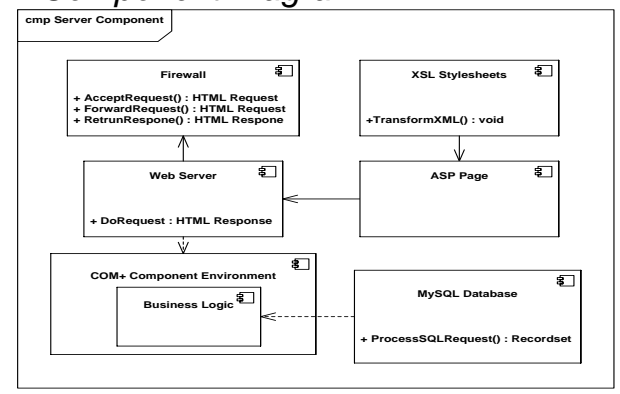

Gambar 10. Component Diagram

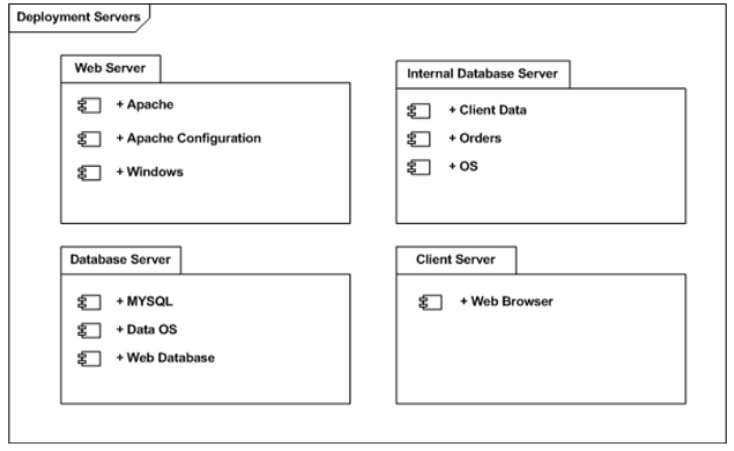

Gambar 11. Deployment Diagram

h. User Interface

1. Halaman Login

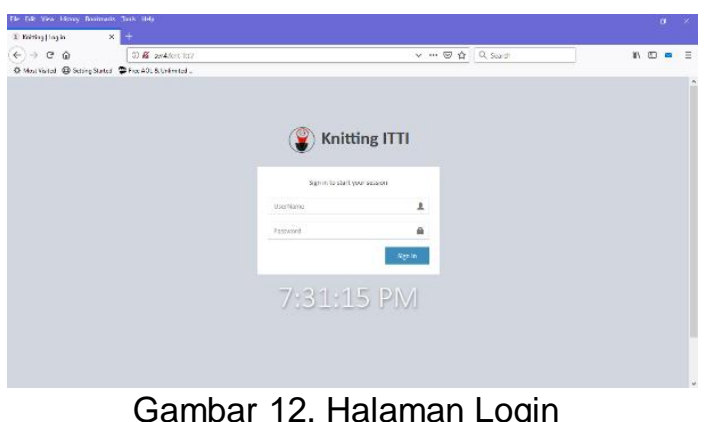

2. Halaman Utama

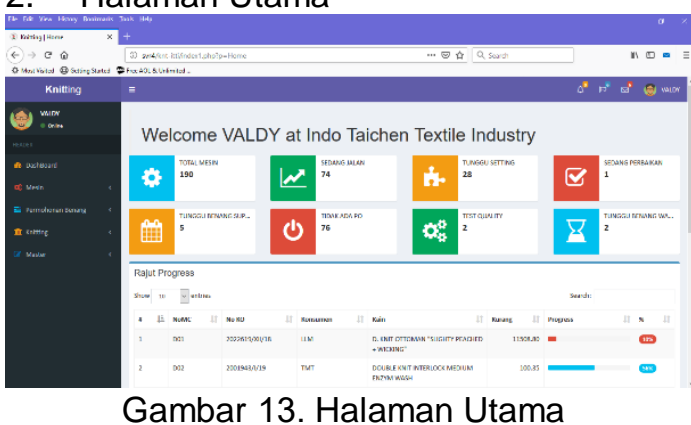

3. Halaman Data Permohonan Benang

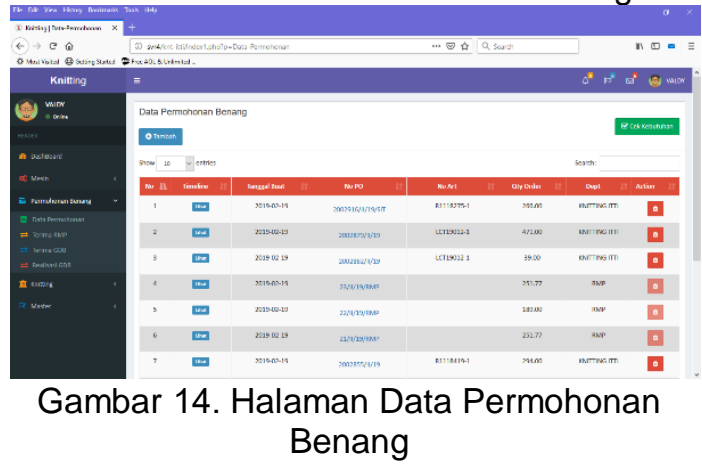

4. Halaman Form Permohonan Benang

g. Deployment Diagram 


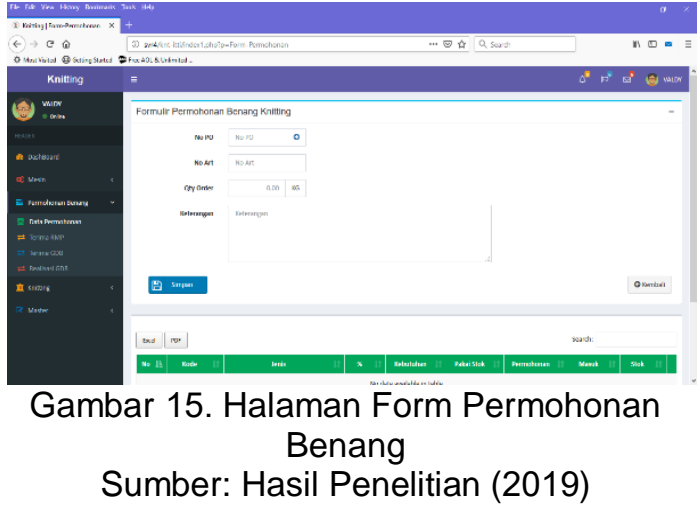

5. Halaman Data Terima RMP

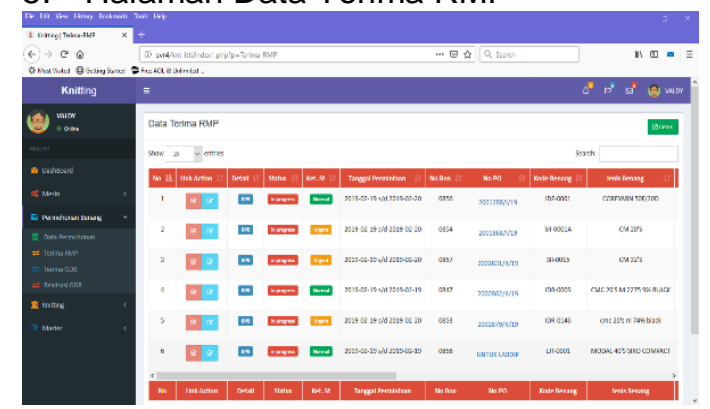

Gambar 16. Halaman Data Terima RMP Sumber: Hasil Penelitian (2019)

6. Halaman DataTerima Gudang Banang

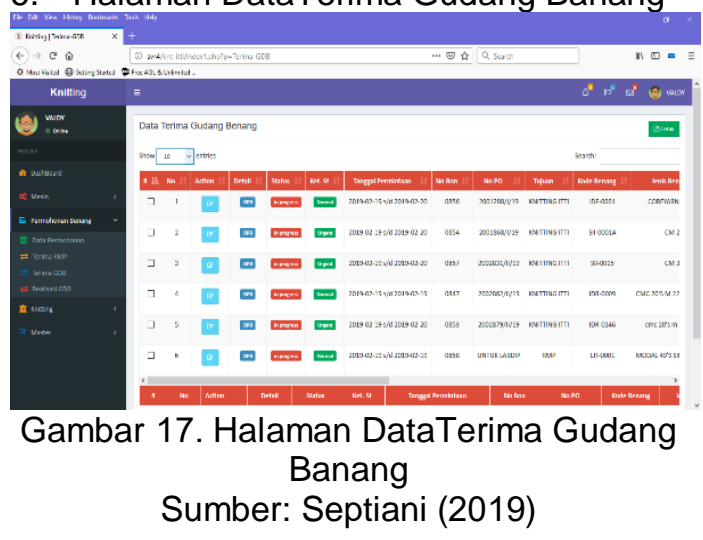

\section{Halaman Data Realisasi Benang}

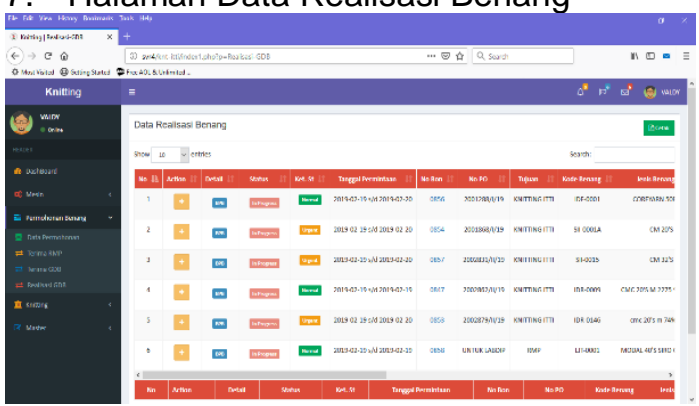

Gambar 18. Halaman Data Realisasi Benang

Sumber: Septiani (2019)

\section{Kesimpulan}

Setelah melakukan serangkaian pembahasan secara terperinci mengenai sistem informasi Permintaan benang pada PT. Indo Taichen Textile Industy yang disusun dalam sebuah jurnal dan didukung dengan pembuatan program berbasis web. Sebagai bahan penutup, maka penulis mencoba menyimpulkan dari semua pembahasan secara singkat. Dan berikut ini kesimpulan yang penulis ambil, yaitu:

Dengan diterapkannya penggunaan teknologi informasi pada PT. Indo Taichen Textile Industy khususnya Departemen Knitting seperti sistem informasi permintaan benang yang berbasis web, maka akan mengurangi kelemahan sistem dan memberikan kontribusi kepada staff Knitting, RMP dan GDB untuk memudahkan dalam memberikan informasi secara mudah, cepat, tepat dan uptodate.

\section{Referensi}

Endra, R. Y., \& Aprilita, D. S. (2018). EReport Berbasis Web Menggunakan Metode Model View Controller Untuk Mengetahui Peningkatan Perkembangan Prestasi Anak Didik. Sistem Informasi Dan Telematika, 9, 15-22.

Fauzi, R. A., \& Hartono, R. (2019). ANALISIS PENGENDALIAN PERSEDIAAN BAHAN BAKU BENANG PADA PRODUK UNDERWEAR DENGAN METODE EOQ (Studi Kasus pada PT. Indonesia Wacoal). Jurnal IImiah Binaniaga, 14(1), https://doi.org/10.33062/jib.v14i1.302

Irawan, A. (2018). Analisa Persediaan Kapas Sintetik Dalam Proses Produksi Benang RHTO65Q12 47, 2 Dengan Menggunakan Metode Economic Order Quantity ( Studi Kasus PT. Kurabo Manunggal Textile Industries ). 1, 8-21.

Pt, D. I., Kurnia, L., \& Sejati, M. (2018). USULAN PENJADWALAN PRODUKSI BENANG MENGGUNAKAN METODE NEH DAN METODE ALGORITMA JOHNSON UNTUK MEMINIMASI WAKTU PRODUKSI DI PT. LAKSANA KURNIA MANDIRI SEJATI Silvi Ariyanti 1), Adianto 2) dan Ricky Miharja 3). 6(3), 157-164. 
Rahmadiansyah, D., \& Irwan, D. (2012). Implementasi Metode Model View Controller Menggunakan Framework Code Igniter dalam Pengembangan Aplikasi Manajemen Depo Petikemas pada Unit Usaha Belawan Logistics Center. Snastikom, (Snastikom), 1-11. Retrieved from https://www.academia.edu/18748092/l mplementasi_Metode_Model_View_C ontroller_Menggunakan_Framework Code_Igniter_dalam_Pengembangan Aplikasi_Manajemen_Depo_Petikem as_pada_Unit_Usaha_Belawan_Logis tics_Center

Septiani, N. A. (2018). Manajemen Proyek Dengan Metode Waterfall Studi Kasus: Pt Indo Taichen Textile Industry. 4(1), 71-76.

Sihombing, M. I. S., \& Sumartini, S. (2018). Pengaruh Pengendalian Kualitas Bahan Baku dan Pengendalian Kualitas Proses Produksi terhadap Kuantitas Produk Cacat dan Dampaknya pada Biaya Kualitas (Cost of Quality). JURNAL ILMU MANAJEMEN DAN BISNIS. https://doi.org/10.17509/jimb.v8i2.126 65
Simamora, Y. K., Puspita, E., \& Herrhyanto, N. (n.d.). SPARE PART LCV BUSHING STRUTHBAR DENGAN. 47-57.

Sitokdana, M. N. N., \& Tanaamah, A. R. (2018). Strategi Pembangunan eCulture di Indonesia. Jurnal Teknik Informatika Dan Sistem Informasi, 2(2).

https://doi.org/10.28932/jutisi.v2i2.439

Utama, A. A. G. S. (2019). EPROCUREMENT SYSTEM PENGADAAN BARANG DAN JASA PADA PT . TRAKINDO UTAMA SURABAYA. 4(1), 592-606.

Wijaya, K., \& Christian, A. (2019). Implementasi Metode Model View Controller ( MVC) Dalam Rancang Bangun Website SMK Yayasan Bakti Prabumulih. $\quad X X I(1), \quad 1-8$. https://doi.org/10.31294/p.v20i2

Wiyana, Y. E. (2012). Analisis Kegagalan Konstruksi Dan Bangunan Dari Perspektif Faktor Non T Teknis. Wahana TEKNIK SIPIL Vol. 17 No. $1 \mathrm{~J}$. 